\title{
NUTRITIONAL STATUS OF RURAL SCHOOL CHILDREN OF DHARWAD AND JHANSI REGION PARTICIPATING IN MID DAY MEAL PROGRAMME
}

\author{
NEHA SINGH ${ }^{1} \&$ CHHAYA BADIGER ${ }^{2}$ \\ ${ }^{1}$ Part of the M. H. Sc., Department of Extension and Communication Management, \\ University of Agricultural Sciences, Dharwad, Karnataka, India \\ ${ }^{2}$ Professor, Department of Extension and Communication Management, \\ College of Rural Home Science, UAS, Dharwad, Karnataka, India
}

\begin{abstract}
School children constitute a major segment of the community whose health and nutritional status will indicate the changing trend of the nutritional profile of a region. With the most prime objective "to improve nutritional status and educational status of school children”, Mid Day Meal Programme (MDMP) was launched on 15th august 1995 as a centrally sponsored programme. The comparative study was conducted in the purposively selected two villages of Garag and Yettingudda of Dharwad district of northern Karnataka and the two villages of Bhojla and Simarddha of Jhansi district of Uttar Pradesh. From each village 30 rural schools were randomly selected for the study. A total of 120 rural school children of $5^{\text {th }}, 6^{\text {th }}, 7^{\text {th }}$ standard belonged to 10-13 years age group were selected purposively for comparison of their nutritional status of the two states. The anthropometric measurements viz., height, weight and mid upper arm circumference were taken to assess their nutritional status through using Indian Academy of Paediatrics (IAP) classification. Suitable statistical parameters were used to analyze the data, such as frequency, percentage, student's $t$ test. The results showed that an equal number of school children (30.00\%) in Dharwad region belonged to Grade II and Grade III malnutrition respectively. Whereas, in Jhansi region, 36.70 percent school children belonged to Grade II malnutrition. The difference in all the means related to height, weight and mid upper arm circumference was not statistically significant in case of both the genders. The mean weight and height of rural school children of both the regions was significantly increased ( $p<0.05)$ according to the age. As comparison, the total mean weight $(29.31 \mathrm{Kg})$ and total mean height $(137.38 \mathrm{~cm})$ of rural school children of Dharwad region was slightly higher than the total mean weight $(28.18 \mathrm{Kg})$ and total mean height $(135.22 \mathrm{~cm})$ of rural school children of Jhansi region. Nutritional status of rural school children of Dharwad region was found better than nutritional status of rural school children in Jhansi region. It can be concluded that the nutritional status of rural school children of Dharwad region was found better than rural school children in Jhansi region.
\end{abstract}

KEYWORDS: Nutritional Status, Akshaya Patra, Mid Day Meal, Rural School Children, Height \& Weight

Received: Aug 12, 2017; Accepted: Sep 02, 2017; Published: Sep 25, 2017; Paper Id.: IJASROCT201739

\section{INTRODUCTION}

The health and nutritional status of the children is an index of the national investment in the development of future manpower. School children constitute a major segment of the community whose health and nutritional status will indicate the changing trend of the nutritional profile of a region. They are the inheritors of our past and seeds of our future. Children contribute to the vital human potential and impart strength to the national economy and development. Nutrition is the most important basic need, being a major determinant of health, labor 
productivity and mental development. Better the nutritional status of the children, higher will be the nation's growth. Protein energy malnutrition (PEM) and certain micronutrient deficiencies continue to be widespread in India. The government introduced the midday meal (MDM) programme in schools on 15th August, 1995 with the objectives of enhancing enrollment, retention of attendance and improving the nutritional status of children. Until the year 2007 the meal was provided to the primary school children only, but thereafter has been extended to 8th standard (middle school). Under the programme, lunch is provided to the children on all working days. As per the government- guidelines the meal served in primary school must provide $450 \mathrm{kcal}$ and $12 \mathrm{~g}$ protein, whereas for the middle school beneficiaries the energy must be $700 \mathrm{kcal}$ and protein $20 \mathrm{~g}$ per child per day. With the most prime objective "to improve nutritional status of school children", Mid Day Meal Programme (MDMP) was initiated on the basis of the philosophy that "when children have "to sit in class with empty stomachs, they cannot focus on learning" (Save the Children India, 2009). Children are the future of mankind. Education and Health are the two basic requirements of children. These primary needs are found to be more basic and urgent for school going children as we go down to the level of primary school. The nation is committed to achieving universalization of Elementary Education Covering Children in the age group of 6 to 14 years. Therefore, an effort was made to compare the nutritional status of rural school children of two states Karnataka and Uttar Pradesh participating in mid day meal programme.

\section{MATERIAL AND METHODS}

The present comparative study was conducted in the purposively selected two villages of Garag and Yettingudda of Dharwad district of northern Karnataka and the two villages of Bhojla and Simarddha of Jhansi district of Uttar Pradesh. From each village 30 rural schools were randomly selected for the study. Purposive sampling method was used to select a total of 120 rural school children of $5^{\text {th }}, 6^{\text {th }}, 7^{\text {th }}$ standard belonged to $10-13$ years of age group to study their nutritional status and comparison of their nutritional status of the two states. The dependent variable taken for the study was the nutritional status of the rural school children participating in mid day meal programme. The anthropometric measurements viz., height, weight and mid upper arm circumference were taken to assess their nutritional status through using Indian Academy of Paediatrics (IAP) classification which uses weight for age as an index to measure nutritional status. Suitable statistical parameters were used to analyze the data, such as frequency, percentage, student's t-test

\section{RESULTS AND DISCUSSIONS}

Table 1 and Figure 1 indicated the frequency distribution of rural school children of Dharwad and Jhansi region based on their gender. In Dharwad region, equal numbers of school children, i.e. 50.00 percent were male and female respectively. Whereas, in Jhansi region, 56.70 per cent of school children belonged to female gender followed by 43.30 percent school children belonged to the male gender. It is evident from Table 1 and Fig. 2 that in both the regions Dharwad and Jhansi, percentage of female gender was equal to 50.00 percent and more than 50.00 percent i.e. 56.70 per cent respectively on gender counterparts. It showed that there was awareness about female education in both the regions. This may be due to the reason that the Government of India has taken many initiatives to promote girls' education throughout the country. Afridi (2004) and Jain and Shah (2005) showed the similar findings.

Table 2 and Figure 2 depict the frequency distribution of nutritional status of rural school children, according to Indian Academy of Pediatrics (IAP) classification. In Dharwad region, equal numbers of rural school children, i.e. 30.00 percent each belonged to Grade II Malnutrition and Grade III Malnutrition respectively, followed by 20.00 percent rural school children belonged to Grade I Malnutrition. On gender counterparts, 36.70 percent of the girls belonged to Grade III 
Malnutrition followed by equal numbers of boys i.e. 33.30 percent each belonged to Grade I \& II Malnutrition respectively and 23.30 percent school children belonged to Grade III Malnutrition. As high as 16.70 per cent rural school children were belonged to normal category in which equal numbers of school children, i.e. 16.70 percent belonged to male and female gender respectively. In Jhansi region, 36.70 per cent of rural school children were belonged to Grade II Malnutrition followed by 28.30 percent rural school children belonged to normal category and 20.00 percent rural school children belonged to Grade I Malnutrition. On gender counterparts, as high as 38.20 per cent rural school children belonged to Grade II Malnutrition followed by equal numbers of boys i.e. 34.60 percent each belonged to Grade I \& II Malnutrition respectively. In both the regions, as high as equal numbers of school children, i.e. 20.00 percent each belonged to Grade I Malnutrition.

\section{Table 1: Frequency Distribution of Rural School Children of Dharwad and Jhansi Region According to Their Gender}

\begin{tabular}{|l|c|c|c|c|}
\hline \multirow{2}{*}{ Gender } & \multicolumn{2}{|c|}{ Dharwad $(\mathbf{n}=\mathbf{6 0})$} & \multicolumn{2}{c|}{ Jhansi (n=60) } \\
\cline { 2 - 5 } & Frequency & Percentage & Frequency & Percentage \\
\hline Boys & 30 & $50.0 \%$ & 26 & $43.3 \%$ \\
\hline Girls & 30 & $50.0 \%$ & 34 & $56.7 \%$ \\
\hline Total & $\mathbf{6 0}$ & $\mathbf{1 0 0 . 0 \%}$ & $\mathbf{6 0}$ & $\mathbf{1 0 0 . 0 \%}$ \\
\hline
\end{tabular}

While comparing the nutritional status of rural school children of both the regions, in Jhansi region, number of school children, i.e. 36.70 percent belonged to Grade II Malnutrition as compared to Dharwad rural school children $(30.00 \%)$ and in case of normal rural school children, number of school children i.e. 28.30 percent belonged to the Jhansi region as compared to Dharwad rural school children (16.70\%).

A close review of Table 2 and Figure 2 showed that in Dharwad region, equal number of (30.00\%) rural school children belonged to Grade II and Grade III malnutrition respectively, and in Jhansi region, as high as 36.70 percent school children belonged to Grade II malnutrition. Even though the midday meal program has encouraged the children to come to school by providing a hot cooked meal, but it provides only one-third of the diet of the school children and the children, mostly skip their breakfast or did not eat breakfast as it is not the routine in most of the households especially in rural areas. Sometimes, children did not eat the meal properly or skip the meal due to the reasons such as watery sambhar, overcooked rice, roti/chappati not cooked properly (Kacchi in local dilect), some of the children bring lunch box from their home, food might be tasty on some days and not on other days. As the majority (58.30\%) of the respondents belonged to joint family, parents sometimes unable to afford the vegetables due to high inflation. So, they did not have sabji and dal both in their menu in home due to which children were not getting proper balanced diet and nutrients from the meal which leads to malnutrition, women's' educational status, food availability and access to safe water. These reasons might be strong reasons which are contributed to the malnutrition of children. The results of the present study are similar to the findings of Srinivasan and Raviprabhu (2004) recorded higher prevalence viz., 78.40 percent of malnutrition among school children in social welfare hostels in Tirupati and Makrudi-Nigeria and Medhi et al. (2006) recorded under nutrition of 50.66 percent in among school age children in Assam, India. Dachna and Prakash (2010) showed a very large percentage of boys and girls were mildly malnourished. 
Table 2: Frequency Distribution of Nutritional Status of Rural School children According to Indian Academy of Pediatrics (IAP) Classification

$(\mathbf{n}=120)$

\begin{tabular}{|l|c|c|c|c|c|c|}
\hline \multirow{2}{*}{ Category } & \multicolumn{3}{|c|}{ Dharwad (n=60) } & \multicolumn{3}{c|}{ Jhansi (n=60) } \\
\cline { 2 - 7 } & Boys & Girls & Total & Boys & Girls & Total \\
\hline \multirow{2}{*}{ Normal } & 05 & 05 & 10 & 07 & 10 & 17 \\
& $(16.70 \%)$ & $(16.70 \%)$ & $(16.70 \%)$ & $(26.90 \%)$ & $(29.40 \%)$ & $(28.30 \%)$ \\
\hline \multirow{2}{*}{ Grade II Malnutrition } & 10 & 08 & 18 & 09 & 13 & 22 \\
& $(33.30 \%)$ & $(26.70 \%)$ & $(30.00 \%)$ & $(34.60 \%)$ & $(38.20 \%)$ & $(36.70 \%)$ \\
\hline \multirow{2}{*}{ Grade III Malnutrition } & 07 & 11 & 18 & 01 & 05 & 06 \\
& $(23.30 \%)$ & $(36.70 \%)$ & $(30.00 \%)$ & $(3.80 \%)$ & $(14.70 \%)$ & $(10.00 \%)$ \\
\hline \multirow{2}{*}{ Grade IV Malnutrition } & 01 & 01 & 02 & 00 & 03 & 03 \\
& $(3.30 \%)$ & $(3.30 \%)$ & $(3.30 \%)$ & $(0.00 \%)$ & $(8.80 \%)$ & $(5.00 \%)$ \\
\hline \multirow{2}{*}{ Grade I Malnutrition } & 07 & 05 & 12 & 09 & 03 & 12 \\
& $(33.30 \%)$ & $(16.70 \%)$ & $(20.00 \%)$ & $(34.60 \%)$ & $(8.80 \%)$ & $(20.00 \%)$ \\
\hline
\end{tabular}

The mean anthropometric measurements of rural school children of Dharwad and Jhansi region by gender are depicted in Table 3 and Table 4 respectively.

\section{Weight}

The mean weight of rural school children of the female gender and male gender was almost equal $29.46 \mathrm{Kg}$ and 29.16 Kg respectively (Table 3 ). The difference in means was not statistically significant in both the genders. The mean weight of rural school children of male gender $(28.4 \mathrm{Kg})$ was slightly higher than the mean weight of female gender (27.9 $\mathrm{Kg}$ ). The difference in means was not statistically significant in both the genders (Table 4).

\section{Height}

The mean height of rural school children of male gender $(138.10 \mathrm{~cm})$ was slightly higher than the mean height of female gender $(136.14 \mathrm{~cm})$. The difference in means was not statistically significant in both the genders (Table 3). The mean height of boys $(137.65 \mathrm{~cm})$ was higher than the mean height of girls $(133.35 \mathrm{~cm})$. The difference in means was not statistically significant in both the genders (Table 4).

\section{Mid-Upper Arm Circumference}

The mean mid upper arm circumference (MUAC) of rural school children of both male and female gender were $18.08 \mathrm{~cm}$ and $18.78 \mathrm{~cm}$ respectively. The difference in means was not statistically significant in both the genders (Table 3 ). The mean mid upper arm circumference (MUAC) of rural school children of both male and female gender were $18.78 \mathrm{~cm}$ and $18.44 \mathrm{~cm}$ respectively. The difference in means was not statistically significant in both the genders (Table 4).

As a comparison, in both the regions, the mean height of boys were higher than the mean height of girls and mean weight of the Dharwad region of both the genders were almost equal whereas, in Jhansi region, there was a slight difference in mean weight of boys and girls, among which boys had higher mean weight than girls. The mean mid upper arm circumference (MUAC) of both the genders in both the regions were almost equal. The difference in means was not statistically significant in both the genders of Dharwad as well as Jhansi region. 
Table 3: Mean Anthropometric Measurements of Rural School Children of Dharwad Region by Gender

$(\mathbf{n}=120)$

\begin{tabular}{|c|c|c|c|c|c|c|c|c|c|}
\hline \multirow{2}{*}{ Gender } & \multicolumn{3}{|c|}{ Weight(kg) } & \multicolumn{3}{|c|}{ Height (cm) } & \multicolumn{3}{|c|}{ MUAC(cm) } \\
\hline & Mean & SD & t- Valı & Mean & SD & t-Value & Mean & SD & t-Value \\
\hline Boy & 29.1667 & 5.20002 & \multirow{2}{*}{$0.189 \mathrm{NS}$} & 138.10 & 6.65582 & \multirow{2}{*}{$0.834 \mathrm{NS}$} & 18.0833 & 2.20142 & \multirow{2}{*}{$1.257 \mathrm{NS}$} \\
\hline Girls & 29.4667 & 6.94179 & & 136.14 & 8.41072 & & 18.7833 & 2.11188 & \\
\hline
\end{tabular}

NS-Non Significant at $0.05 \%$ level

Table 3 indicated that the mean weight of Dharwad female and male gender was almost equal, i.e. $29.46 \mathrm{Kg}$ and 29.16 Kg respectively. The mean mid upper arm circumference of Dharwad female and male was $18.78 \mathrm{~cm}$ and $18.03 \mathrm{~cm}$ respectively, and the mean height of Dharwad female and male was $136.14 \mathrm{~cm}$ and $138.10 \mathrm{~cm}$ respectively. There was no statistically significant difference in the mean weight, height and mid upper arm circumference of Dharwad boys and girls. The mean height of girls is higher at the ages 10,11, 12 and 13 than the boys. Saheb and Rajendra Prasad (2009) showed similar results regarding slightly higher mean weight of girls compared to boys. The girls also have slightly higher mid upper arm circumference than boys.

Table 4: Mean Anthropometric Measurements of Rural School Children of Jhansi Region by Gender

$(\mathrm{n}=\mathbf{1 2 0})$

\begin{tabular}{|c|c|c|c|c|c|c|c|c|c|}
\hline \multirow{2}{*}{ Gender } & \multicolumn{3}{|c|}{ Weight(kg) } & \multicolumn{3}{|c|}{ Height $(\mathrm{cm})$} & \multicolumn{3}{|c|}{ MUAC $(\mathrm{cm})$} \\
\hline & Mean & SD & t- value & Mean & SD & t-value & Mean & SD & t-value \\
\hline Boys & 28.4615 & 4.25423 & \multirow{2}{*}{$0.360 \mathrm{NS}$} & 137.65 & 9.76501 & \multirow{2}{*}{$1.716 \mathrm{NS}$} & 18.7808 & 1.57023 & \multirow{2}{*}{$0.796 \mathrm{NS}$} \\
\hline Girls & 27.9706 & 5.87488 & & 133.35 & 9.50879 & & 18.4412 & 1.68669 & \\
\hline
\end{tabular}

NS-Non Significant at 0.05 Levels

Table 4 revealed that the mean weight of Jhansi male gender $(28.4 \mathrm{Kg})$ was slightly higher than the mean weight of female gender $(27.9 \mathrm{~kg})$, the mean height of boys $(137.65 \mathrm{~cm})$ was higher than the mean height of girls $(133.35 \mathrm{~cm})$ and the mean mid upper arm circumference of boys $(18.78 \mathrm{~cm})$ was slightly higher than the girls $(18.44 \mathrm{~cm})$. There was no statistically significant difference in the mean weight, height and mid upper arm circumference of Jhansi boys and girls. This showed that boys have more mean height, weight and mid upper arm circumference than girls.

The probable reason for girls showing slightly higher weight and mid upper arm circumference than boys in Dharwad region and boys showing higher mean height, weight and mid upper arm circumference than girls in Jhansi region may be that girls begin their adolescent growth spurt, which shoots up their growth rate at an earlier age of the school age period but afterwards the boys speed up their growth and overtook the girls during later stage of school age period. Other contributing factors may be that even though boys and girls were having their midday meal and study in the same school without any gender discrimination, but the different family setups, gender bias, parental preferences for male children and genetic factor in Indian society may contribute to the less anthropometric measurements of girls as compared to boys.

Table 5: Mean Anthropometric Measurements of Rural School Children of Dharwad Region by Age

$(n=60)$

\begin{tabular}{|c|c|c|c|c|c|c|}
\hline \multirow{2}{*}{ Age (Yrs) } & \multicolumn{3}{|c|}{ Weight(kg) } & \multicolumn{3}{c|}{ Height (cm) } \\
\cline { 2 - 6 } & Mean & SD & F- value & Mean & SD & F-Value \\
\hline 10 & - & - & \multirow{2}{*}{$4.60^{*}$} & - & - & \multirow{2}{*}{$7.30^{*}$} \\
\cline { 2 - 3 } & 26.1579 & 2.77415 & & 132.89 & 5.74354 & \\
\hline
\end{tabular}




\begin{tabular}{|c|l|l|l|l|l|l|}
\hline 12 & 30.0000 & 6.64831 & & 137.43 & 8.48276 & \\
\cline { 1 - 2 } & 31.6000 & 6.71526 & & 141.30 & 5.86784 & \\
\cline { 1 - 2 } \cline { 5 - 6 } & & & 137.28 & 7.56462 & \\
\hline
\end{tabular}

*Significant at 0.05 level

Table 6: Mean Anthropometric Measurements of

Rural School Children of Jhansi Region by Age

$(n=60)$

\begin{tabular}{|c|c|c|c|c|c|c|}
\hline \multirow{2}{*}{ Age (Yrs) } & \multicolumn{3}{|c|}{ Weight (kg) } & \multicolumn{3}{|c|}{ Height (cm) } \\
\hline & Mean & SD & F-value & Mean & SD & F-value \\
\hline 10 & 25.8235 & 3.64409 & \multirow{5}{*}{$8.81 *$} & 129.88 & 6.46029 & \multirow{5}{*}{$7.63 *$} \\
\hline 11 & 26.4375 & 2.73176 & & 131.62 & 4.52953 & \\
\hline 12 & 29.7500 & 5.68178 & & 139.92 & 11.39381 & \\
\hline 13 & 38.3333 & 2.88675 & & 147.00 & 4.58258 & \\
\hline Total & 28.1833 & 5.19939 & & 135.22 & 9.77734 & \\
\hline
\end{tabular}

*Significant at 0.05 level

Table 5 \& 6 indicated the mean anthropometric measurements of rural school children of Dharwad and Jhansi region by age respectively.

\section{Weight}

The mean weight of rural school children from the age of 13 years was $(31.6 \mathrm{Kg})$ followed by mean weight (30.0 $\mathrm{Kg}$ ) for the age of 12 years and mean weight $(26.15 \mathrm{Kg})$ for the age of 11 years school children. The mean weight of rural school children was significantly increased $(\mathrm{p}<0.05$, Table 5). The mean weight of rural school children from the age of 13 years was $(38.33 \mathrm{Kg})$ followed by mean weight $(29.75 \mathrm{Kg})$ for the age of 12 years, mean weight $(26.43 \mathrm{Kg})$ for the age of 11 years school children and mean weight $(25.82 \mathrm{Kg})$ for the age of 10 years school children The mean weight of rural school children was significantly increased $(\mathrm{p}<0.05$, Table 6$)$.

\section{Height}

The mean height of rural school children from the age of 13 years was $(141.30 \mathrm{~cm})$ followed by mean height $(137.43 \mathrm{~cm})$ for the age of 12 years and mean height $(132.89 \mathrm{~cm})$ for the age of 11 years school children. The mean height of rural school children was significantly increased $(\mathrm{p}<0.05$, Table 5$)$. The mean height of rural school children from the age of 13 years was $(147.00 \mathrm{~cm})$ followed by mean height $(139.92 \mathrm{~cm})$ for the age of 12 years, mean height $(131.62 \mathrm{~cm})$ for the age of 11 years school children and mean height $(129.88 \mathrm{~cm})$ for the age of 10 years school children The mean height of rural school children was significantly increased $(\mathrm{p}<0.05$, Table 6$)$.

As comparison, the total mean weight $(29.31 \mathrm{Kg})$ of rural school children of Dharwad region is slightly higher than the mean weight of rural school children $(28.18 \mathrm{Kg})$ of Jhansi region. A similar trend was observed in the case of height the total mean height $(137.28 \mathrm{~cm})$ of rural school children of Dharwad region is higher than the mean height of rural school children $(135.22 \mathrm{~cm})$ of Jhansi region.

It is evident from Table 5 that the mean weight of rural school children of Dharwad region who belonged to the age of 13 years is $31.60 \mathrm{Kg}$ followed by the school children of age of 12 years $(30.00 \mathrm{Kg})$ and school children of 11 years of age $(26.15 \mathrm{Kg})$. The mean height of school children of 13 years is $141.30 \mathrm{~cm}$ followed by children of 12 years $(137.43$ $\mathrm{cm})$ and 11 years $(132.89 \mathrm{~cm})$. It can be clearly observed that there was a significant difference in mean weight and height of schoolchildren with their age. 


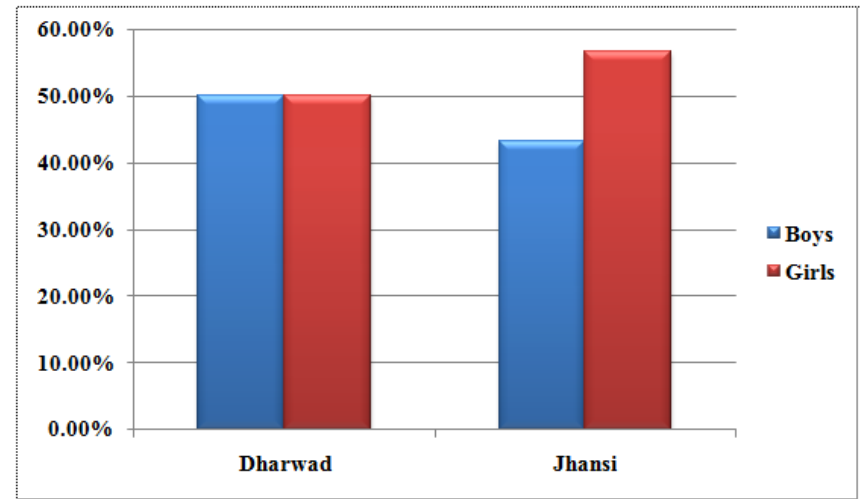

Figure 1: Frequency Distribution of Rural School Children of Dharwad and Jhansi Region According to Their Gender

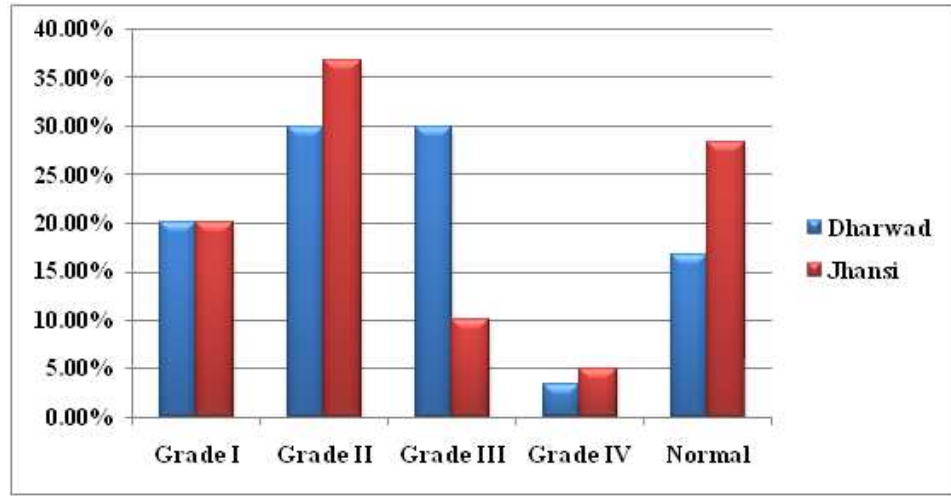

Figure 2: Frequency Distribution of Nutritional Status of Rural School Children According to Indian Academy of Pediatrics (IAP) Classification

A close review of Table 6 showed that the mean weight of rural school children of Jhansi region who belonged to the age of 13 years is $38.33 \mathrm{Kg}$ followed by the school children of age of 12 years $(29.75 \mathrm{Kg})$ than school children of 11 years of age $(26.43 \mathrm{Kg})$ and school children of 10 years $(25.82 \mathrm{Kg})$. The mean height of school children of 13 years is $147.00 \mathrm{~cm}$ followed by children of 12 years $(139.92 \mathrm{~cm})$ than 11 years $(131.62 \mathrm{~cm})$ and school children of 10 years age $(129.88 \mathrm{~cm})$. It can be clearly observed that there was a significant difference in mean weight and height of schoolchildren with their age.

From Table 5 and 6, it can be observed clearly that the mid day meal program helped in achieving height and weight according to the age group. Total mean weight and height of Dharwad school children was higher than the school children of Jhansi region.

\section{CONCLUSIONS}

Thus, it can be concluded by comparing the nutritional status of rural school children of both the regions, in Jhansi region, number of school children, i.e. 36.70 percent belonged to Grade II Malnutrition as compared to Dharwad rural school children $(30.00 \%)$ and in case of normal rural school children number of school children i.e. 28.30 percent belonged to the Jhansi region as compared to Dharwad rural school children (16.70\%). The difference in means related to weight, height and mid-upper arm circumference were not statistically significant in both the genders. The mean weight and height of rural school children was significantly increased $(\mathrm{p}<0.05)$ according to their age group. The mid day meal program 
helped in achieving height and weight according to the age group. Total mean weight and height of Dharwad school children was higher than the school children of Jhansi region, the most important contributing factor was public-private partnership in Karnataka state.

\section{REFERENCES}

1. Afridi, F., Barooah, B. and Somanathan, R., 2013, School Meals and Classroom Effort: Evidence from India. Int. growth center, 8(2): 1-29.

2. Bellary, N. A., Karkannavar, J. S. and Bharati, P., 2011, Information and Opinion of Beneficiaries on Akshara Dasoha programme in Hubli City of Karnataka. Indian J. Nutr. Dietet., 48:268-274.

3. Tushar Nale, M. K. Chavan, Hemant Mahajan \& Gd Velhal, Disentangling the Influence of Maternal Factors on Nutritional Status of Children:Community Based Study in an Urban Slum of India, International Journal of General Medicine and Pharmacy (IJGMP), Volume 2, Issue 1, February 2013, pp. 45-54

4. Dachana, K.B., Divya Prakash, J. and Jamuna Prakash, Mid day meal programme- A comprehensive analysis of operational constraints and impact of training on the personnel involved in selected schools. Ind. J. Nutr. Dietet., 47:435-443.

5. Devdas, R.P., Shekhar, C.V., Dhodi, K.L., 1974, Evaluation of Low Cost Indigenous Food Supplements to the Schools Lunch. Indian J. Dietet., 11: 127-132.

6. Prashanthi Meda et al., Assessment of Nutritional Status of Adolescent Girls of Medchal Mandal Rangareddy District, International Journal of Agricultural Science and Research (IJASR), Volume 7, Issue 4, July - August 2017, pp. 731-736

7. Jain, J. and Shah, M., 2005, Antyodaya Anna Yojana and Mid Day Meals in M.P. Economic political weekly, 11: 5076-5088.

8. Jelliffee, D.B., 1966, The Assessment of the Nutritional Status of the Community. Monograph Series, 53:20-23.

9. Medhi, G. K., Barua, A. and Mahanta J., 2006, Growth and nutritional status of school age children (6-14 years) of tea garden worker of Assan. J. Human Ecol., 19:83-85.

10. Rana, K., Santra, S., Banerjee, T., Mukherjee, A. and Kundu, M., 2005, Cooked Mid Day Meal Programme in West Bengal- A studying Birbhum district Pratichi (India) Trust New Delhi.

11. Save the Children India, 2009, "Freedom from Hunger for Children under Six", New Delhi: Save the Children India

12. Srinivasan, K. and Raviprabhu, G., 2004, A study of the nutritional status of children in social welfare hostels in Tirupati, A.P. The Ind. J. Nutr. Dietet., 41:210-214. 